Received September 16, 2019

Revised December 18, 2019

Accepted December 19, 2019

\title{
Norm Internalization and Disability-inclusive Elections in the Philippines
}

\author{
PAULA BIANCA P. LAPUZ ${ }^{*}$ AND FRANCISCO A. MAGNO**
}

This article reviews the emergence of international norms connected with disability-inclusive elections and provides evidence of how they were cascaded and internalized in the Philippines. It examines the experience of the persons with disabilities (PWD) sector in the campaign for disability-inclusive elections. With the support of civil society organizations and international development partners, the PWD sector lobbied for the passage of the Accessible Polling Place (APP) Act which aims to improve the enfranchisement of PWDs. Primary data were collected through key informant interviews and focus group discussions, while a contextual analysis of relevant secondary documents was conducted to show proof of norm internalization in the establishment of disabilityinclusive elections.

Keywords: Disability, persons with disabilities, disability-inclusive elections, norm diffusion, norm life cycle, policy entrepreneurs, electoral reforms

* Lecturer, Far Eastern University, Philippines; E-mail: plapuz@feu.edu.ph

**Associate Professor, De La Salle University, Philippines;

E-mail: francisco.magno@dlsu.edu.ph

DOI: $10.16934 /$ isr.20.2.201912.53 


\section{INTRODUCTION}

Despite making up at least 15 percent of the global population (World Health Organization 2011), persons with disabilities (PWDs) have been tagged as one of the excluded groups in society since the 1970s (Sen 2000). They are discriminated in opportunities for employment (Mercat-Bruns 2016; Shier, Graham, and Jones 2009), health (Thompson, Stancliffe, Broom, \& Wilson, 2014), education (Peters 2008; Kearney 2016), and participation in community life (Fumarco 2017; Park 2017). More specifically, women with disabilities suffer from multiple discrimination due to the intersectionality of their gender, disability, and social status (Samararatne and Soldatic 2015; Holness 2016; Senne 2016).

Globally, a 2015 study by the International Centre for Evidence in Disability (ICED) observed high links between poverty and disability in $80 \%$ of epidemiological studies they reviewed from low to middle income countries (ICED 2015). Conversely, including PWDs in development initiatives can lead to economic, social, and political gains for any country. In particular, improving their access to political spaces may be viewed as an entry point toward enhancing the quality of their lives.

In 2006, the UN Convention on the Rights of Persons with Disabilities (CRPD) was passed with Article 29 insisting on the right to political participation of PWDs. Since then, the convention has been either signed or ratified by many countries. However, not all states were able to come up with a national law in pursuit of the international norms laid down in the CPRD. This article grapples with the research problem of how norm diffusion leads to successful policy creation. The case of the Philippines was chosen as it presents a good illustration of how norm diffusion took place and the role of domestic actors in both adoption and commitment to the norm.

This study builds on the work of Finnemore and Sikkink (1998) where norms are defined as the standard of appropriate behavior for actors with a given identity. They offer three-stage norm life cycle model that illustrates how norms influence domestic politics. At the norm emergence stage, norm entrepreneurs through organizational platforms convince a critical mass of states to adopt new norms. As these norms permeate international governance structures, powerful states socialize other states into subscription and adherence to the set of new norms generally through peer pressure or the norm cascade stage as evidenced by documented signs of commitment. These first two stages are marked by tipping points or thresholds that demonstrate the relevant states' acceptance of the new norms. Finally, at the last stage, norms stop being contentious and are therefore internalized by societies. Various actors, motives, and mechanisms of influence define all these stages.

The norm life cycle is invaluable especially in describing how norms 
travel from the international community down to the states, but provides little guidance in showing how exactly states internalize norms. Zwingel (2012) contemplates on this and asserts that norm adoption and translation is contextpecific and therefore rests primarily on "cross-cultural negotiations". She laments that global-centric macro theories on norm diffusion, trans-nationalization and regime analysis when applied to different situations will inevitably result into varied forms, thus, will not be able to generate more reflective insights about the impact of norms on domestic politics.

To respond to this, we propose a modified version of the norm life cycle to capture the dynamics of norm internalization, specifically in domestic policy-making. We argue that the fundamental proof of norm internalization will always be the adoption of national laws that are aligned with international norms as states remain as the main agents of norm institutionalization. However, we differentiate between agreements, which only represent the symbolic commitment of states to international treaties advancing new norms, and laws which define how such commitments are translated into operational policies. We argue that policy changes that lead to the institutionalization of norms provide a solid basis for the evaluation of norm internalization.

By expanding the selection of possible actors and expounding on the dominant mechanisms that influence norm internalization, we demonstrate how stakeholders interact at the domestic level and use international norms to pursue policy reform. This modified framework strengthens the norm life cycle model by reflecting on the political dynamics that enabled norm internalization. Through this, we show that norm internalization is not a static, top-down process, but is marked instead by contestation, deliberation, and cooperation among different groups. At the same time, we provide a viable explanation as to why states adopt electoral reforms that do not lead to demonstrable additions to the power of the political elite.

Drawing from the public policy literature, we added policy entrepreneurs, institutional reformers, and civil society advocates in the policy ecosystem. In this regard, it is crucial to stress the role of coalition building and grassroots mobilization in policy change to explain the primary dominant mechanism for norm internalization, which is institutionalization (Jeon and Haider-Markel 2001).

Jeon and Haider-Markel (2009) describe policy entrepreneurs as actors in the policy process who engage in significant action to initiate policy change particularly in the areas of defining problems, networking in policy communities, shaping the scope and terms of policy debate, and building coalitions. Studies indicate that policy entrepreneurs generate impact when they harness networks or when they forge collaboration with both insiders and outsiders. Hence, institutional reformers who hold relevant positions in the bureaucracy are critical players in 
domestic policy reform. Meanwhile, advocates, are interest groups who devote efforts to influence policymaking. Apart from the said actors, the media also has the capacity to expand the attention given to specific issues and can invite broader participation in the policy discourse.

At the same time, Kimberlin (2009) highlights the contribution of Watson (1993) in the policy change analysis by underscoring the importance of coalition building and grassroots mobilization efforts in the enactment of the American with Disabilities Act (ADA). The US disability rights movement effectively gathered together various disability organizations and individuals with different types of disabilities. This unified network of advocates collaborated with other civil rights organizations in lobbying with policymakers and different stakeholders to control the tempo of the policy debates surrounding the ADA and rally support for the policy proposal. All these find parallels in the passage of the 2013 Accessible Polling Places (APP) Act, or Republic Act No. 10366, in the Philippines and they can help explain the said policy change as evidence of how norm internalization fostered disability-inclusive elections in the country.

\section{METHODOLOGY}

This study employed qualitative research methods in assessing how the different actors, including policy entrepreneurs, institutional reformers, and civil society advocates participated in the process of norm diffusion, adoption, and internalization that shaped strategic actions leading to the passage of disabilityinclusive elections embodied in the 2013 APP Act. Qualitative research usually considers how actors in a social setting view their circumstances through the prism of social relationships, roles and actions (Lune and Berg 2017). It provides an effective way of narrating events and circumstances at the time of the norm diffusion and policy creation supportive of disability-inclusive elections. Document analysis, key informant interviews, and focus group discussions were undertaken as part of the triangulation of data in qualitative research. By triangulating data, the effort is made to supply a basin of sound evidence (Eisner 1991).

Document analysis entails probing, choosing, scrutinizing and synthesizing data found inside the documents (Bowen 2009). Key informant interviews (KIIs) were made with influential leaders similar to previous studies on disability policy (O'Day and Goldstein 2005). In this regard, KIIs were conducted with former and current officials of the Commission on Elections (COMELEC) and the National Council on Disability Affairs (NCDA), as well as representatives of donor agencies and election field offices. On the other hand, focus group discussions (FGDs) provide a suitable avenue for validating collective views on 
social issues (Lloyd-Evans 2006). FGD sessions were held with members of PWD organizations to ascertain their shared perspectives on their role in the advocacy for disability-inclusive elections.

\section{THE NORM LIFE CYCLE}

\section{Disability-Inclusive Elections Norm Emergence}

The second world war inspired a sustained ideational commitment of norm entrepreneurs in promoting human rights and the peaceful resolution of conflicts under the newly formed United Nations (UN) as an organizational platform (Katz-Suchy, 1948). In the case of disability rights, relevant international norms can be said to have initially developed in the 1970s, following an increased awareness regarding exclusions faced by certain groups of people.

The UN acknowledged the discrimination faced by persons with disabilities on account of their identity and adopted the Declaration on the Rights of Mentally Retarded (the term has changed since then) in 1971 and the Declaration on the Rights of Disabled Persons in 1975. The year 1981 was similarly declared in the 1975 UN General Assembly (GA) as the International Year of the Disabled Persons. That year produced the World Programme of Action Concerning Disabled Persons or the first international reference material that asserted the use of human rights lens in tackling disability issues, which was adopted by the UN GA in 1982. The same GA declared the years 1983 to 1992 as the UN Decade of Disabled Persons. Among the crucial outputs of the decade was the Standard Rules on the Equalization of Opportunities for Persons with Disabilities adopted by the UN GA in 1993 that provided a concrete mechanism for the states to operationalize promotion and protection of disability rights. This also marked a shift in referencing to the sector from disabled persons to persons with disabilities, which acknowledges the person first before the disability.

During the years 1993, 1998, 1999, and 2003 the UN hosted various international meetings and seminars that encouraged states to transform the Standard Rules into national policies (Lapuz 2017). Subsequently, the UN Economic and Social Commission for Asia and the Pacific (UNESCAP) pronounced the years 1993 to 2002 and 2003 to 2012 as the Asian and Pacific Decades of Disabled Persons, around 690 million persons with disabilities reside in the region (UN-ESCAP 2017).

Policy entrepreneurs like the International Foundation for Electoral Systems (IFES) and the International Institute for Democracy and Electoral Assistance played a leading role in advancing the concept of disability-inclusive elections. A quick visit to the official website of the IFES indicates that among its 
core focus areas is participation and inclusion, under which they pursue their initiatives for citizen empowerment including their projects that promote disability-inclusive elections. In 2011, the IFES partnered with disabled people's organizations and election-focused civil society organizations to form the General Election Network for Disability Access (AGENDA). The network organized a regional dialogue where participants produced the Bali Commitments on Equal Access to Elections stipulating guidelines to remove barrier to electoral participation (AGENDA 2016).

Before these developments, disability policies were generally oriented towards the medical and/or charity model of disability. However, since the development of the social model of disability, disability came to mean as a condition that emanated not only from bodily and mental impairments but also from disabling built environments and society's discriminatory behavior toward PWDs (Oliver 1990). The social model inevitably aligned with the rights-based framework of disability that asserted the need for government intervention to provide the PWDs with access to the basic social services and the enjoyment of fundamental human rights. All of the above represent tipping points for norm emergence in disability rights.

\section{Disability-Inclusive Elections Norm Cascade}

\section{1) Global Level}

The gathering of a critical mass of states as regards disability rights happened during the adoption of the UN Convention on the Rights of Persons with Disabilities (UN-CRPD) in 2008. We consider this phase as Stage 2 for two main reasons, first, it was the initial legally binding international treaty on disability rights; and second, it officially marked the adherence of the international community to the social model of disability over the medical and/or charity model. The deliberations covering the UN-CRPD were completed after only eight sessions of the UN GA's Ad Hoc Committee, which the UN stated was the fastest process achieved for any human rights treaty in the history of the UN (UN-DESA n.d.).

At this stage, states respond to peer pressure by signing treaties for the following reasons: 1) to increase their legitimacy back home and internationally; 2) to conform, so as to fulfill the psychological need to be part of a group; and lastly; 3) to build esteem, to be held in high regard by themselves and others (Finnemore and Sikkink 1998, 903). This is consistent with observations found in the literature where states are observed to commit to treaties depending on the perceived benefits and costs of implementation, specifically in the areas of domestic legal enforcement and collateral consequences (Hathaway 2007). 
In the case of disability rights, states that will refuse to commit to promoting and protecting PWDs will run the risk of creating an unappealing image for themselves, considering how exclusion of persons with disabilities are attached to accounts of historical injustice and disempowerment. Currently, 164 countries, including the Philippines, have not only signed the convention but also ratified the treaty through parliamentary procedures (UN-DESA n.d.).

The UN-CRPD enumerates the political, economic, and social rights of persons with disabilities, including the right to vote and to stand as candidates in elections. All over the world, exclusionary electoral policies and practices are being contested and engaged primarily based on the rights-based approach to electoral participation as articulated in the treaty, and earlier in the UN-ICPR (Schur and Adya 2013; Schur, Adya and Ameri 2015; Schur, Ameri and Adya 2017; Virendrakumar, Jolley, Badu, and Schmidt 2018; Spagnuolo and Shanouda 2017; Priestley et al. 2016; Redley 2008).

\section{2) Regional Level}

Following the enactment of the UN-CRPD, the IFES as a policy entrepreneur led the advocacy for the creation of disability-inclusive elections. In particular, it provided technical and funding support to create the General Network for Disability Access (AGENDA) in 2011, which served as an organizational platform within Southeast Asia, specifically covering the Philippines, Indonesia, Vietnam, Lao PDR, and Cambodia for organizations of persons with disabilities. The network undertook baseline research, pioneered capacity building activities, and hosted multi-stakeholder consultations on accessible elections and produced the first report on the status of disability laws and compliance of states in the region with international norms on disability rights, specifically political participation (AGENDA 2013).

In 2014, the IFES together with the National Democratic Institute which is another international NGO dedicated to spreading democratic ideals with funding from the United States Agency for International Development (USAID), published a manual meant to assist electoral bodies in redesigning election systems to provide reasonable accommodation to PWDs and enfranchise them (IFES and NDI 2014).

The Association of Southeast Asian Nations (ASEAN) Intergovernmental Commission on Human Rights also served as an organizational platform through which disability rights were promoted. In 2011, ASEAN leaders signed the Bali Declaration on the Enhancement of the Role and Participation of Persons with Disabilities in the ASEAN Community and declared the period from 2011 to 2020 as the ASEAN Decade of PWDs (AGENDA 2013). 


\section{Accessible Polling Places Act: Providing Evidence on Norm Internalization}

According to a Filipino PWD leader who was part of the FGD for this research, the original treaty for political inclusion - the International Covenant on Civil and Political Rights (ICCPR) adopted by the UN in 1966 - was supposed to be pursued on the premise that political rights should not come with too much costs. Thus, it should not be difficult to implement.

The focus on the right to vote for the PWD community in the Philippines, consistent with other developing countries, began generally after the adoption of the UN-CRPD in 2008 and its subsequent ratification at the state level (Kirakosyan 2016; Lord, Stein and Fiala-Butora 2014; Harpur 2012). The UN-CRPD explicitly sought to ensure the availability of accessible voting via the secret ballot to PWDs, among other socio-political and economic rights.

A PWD leader who formerly served in government and whom we interviewed for this research noted that prior to the UN-CRPD, it was hard to imagine that PWDs would actively participate in the polls. This goes to show that the UN-CRPD indeed created a targeted impact on the PWD sector in a way that the UN-ICCPR did not expect because prevailing domestic norms countered the idea of "universal human rights".

The UN-CRPD strengthened the imperative for disability-inclusive elections. Norm entrepreneurs like the IFES and eventually The Asia Foundation (TAF) collaborated with officials from the Commission on Human Rights (CHR) and the COMELEC (i.e. policy champions) and advocates from civil society to increase the involvement of organizations of PWDs in policy-making and election monitoring (i.e. coalition building and grassroots mobilization).

Generally, the existing literature shows that exposure to transnational activist networks that reciprocate messages for human rights and more political inclusion and the availability of donor aid supporting democratization galvanized local civil society action, improve capacities of election management bodies, and sustain inclusive elections campaigns (Skinner 2017; Caraway 2004; Sapire 2009; Wright 2009; Savun and Tirone 2011).

In this part, we examine how disability-inclusive elections norms were internalized in the Philippines through the legislation of the APP Act, which was in turn strategically supported by norm entrepreneurs. By doing so, we accomplish two crucial contributions to the literature: 1) address the weakness of the norm life cycle model by referring to the legislation of laws that aim to operationalize the state's commitment toward advancing new international norms instead of just symbolic policies such as those made to ratify international treaties to prove norm internalization and 2) provide an explanation as to why states adopt inclusive electoral reforms, which is currently not captured in existing electoral reform studies. 
Like the IFES, a cursory review of TAF's website also shows their interest in elections, specifically in voter registration and education, among others, to help promote democratic governance. Both organizations have dedicated considerable resources toward organizing the PWD sector in the Philippines to lobby for and participate in the formulation of the APP Act and its subsequent Implementing Rules and Regulations (IRR). This shows that the concept of disability-inclusive elections permeated the Philippines through the said transnational actors.

The work of the IFES in the Philippines started in 1998 when it assisted the COMELEC in improving its mandatory functions such as voter education, training, and building relationships with the media. Generally with funding from the USAID, the succeeding years saw the IFES supporting initiatives in the country connected with modernizing the electoral system and increasing the capacities of civil society to lobby for electoral reforms, among them disability related policies (IFES 2009).

The support rendered by the IFES to the COMELEC and civil society organizations focused on transferring knowledge and building skills for a more credible, transparent and inclusive conduct of elections. In 2009, its elections expert facilitated the workshop of the poll body's newly formed Project Management Office, which was tasked to oversee the administration of the automated elections. The IFES technical assistance gave COMELEC officials and senior staff with learning programs on election best practices abroad (i.e. indigenous voting) through relevant trainings and short study trips. It also supported the development of a legal framework for electoral reforms. These interfaced with their work with civil society in reviewing election laws, monitoring electoral processes, and increasing the electoral participation of sectors vulnerable to disenfranchisement, which included persons with disabilities (IFES 2009).

During the years that the APP bill was drafted and lobbied in the Philippine Legislature or Congress, the IFES had a full staff and office working closely with the COMELEC. Domestically, the country was primed for the APP law not only from the successful norm diffusion but also from the heightened awareness the previous election-related policy reforms have generated. Given the multiple electoral issues that the Philippines faced, the policy entrepreneurs and their institutional partners saw the APP law as a low-hanging fruit for policy reform.

The IFES supported the launch of the campaign for disability-inclusive elections in the Philippines through the Conference on "Ensuring the Right (of Vulnerable Sectors) to Electoral Participation" organized by the CHR in 2008 (CHR 2008). The campaign coincided with the ratification of the UN-CRPD in the Philippines in the same year.

This forum was significant for two main reasons. First, the CHR's 
involvement in the campaign indicated a paradigm shift on how disability is understood in the Philippines. Disability was now officially viewed in the country as a social condition, representing a departure from the limits of the medical and/or charity models, that require targeted policy solutions. Second, the activity also signified a similar impending shift in the orientation of polls in the country towards a rights-based framework. These indicate that disability-inclusive elections norms have begun permeating Philippine politics and concrete actions to push for its operationalization were being contemplated by the national government as well as civil society. The strategic agenda of the IFES reflected these concerns in their Philippines Election Reform Project during the period of 2007 to 2009 (IFES 2009).

Through the 2008 Conference, the CHR committed to help improve the enfranchisement of PWDs, elderly, detainees, indigenous peoples (IP), internally displaced persons (IDP), and the youth, recognizing that the right to vote of individuals belonging to these sectors were constricted by government inaction, lack of resources and political will, or inadequate legal framework (CHR 2008).

The said endeavor was jointly organized with Task Force 2010 (TF2010), a network of election watchdogs similarly created with the support of the IFES. Prior to TF2010, only the youth and migrant [i.e. for overseas absentee voters] groups held separate mainstream campaigns for the enfranchisement of their constituencies (Bagas 2004.; Velasco 2005; CMA 2011), which themselves were supported by international donors such as the Friedrich Ebert Stiftung. As such, TF2010 provided an opportunity for the civil society organization to come together and advance shared interests, thus giving them a stronger capacity to negotiate policies in their favor.

The institutionalization of disability-inclusive elections would not have been possible without the active involvement of the said network because this "coming together" of civil society groups meant that less organized sectors such as the PWDs, IPs, and persons deprived of liberty could benefit from the professional capacities of the social movements like the youth and migrants in campaigning for inclusive elections. It also meant that the weaker social minority groups need not compete when it came to policy agenda setting with the bigger and more empowered sectors. All social minorities instead cooperated, which increased their lobbying and bargaining powers with the COMELEC and the legislature. Prior to this, no other initiative on electoral reforms attempted to create a campaign that banked on solidarity among marginalized groups. This could not have taken place if IFES, with support from local electoral reform experts, did not organize the groups together.

It was during the 2008 CHR Conference that PWDs first mentioned their suggestion to policy-makers to have "special polling places at the ground level of voting centers" dedicated for them. In addition, PWDs also suggested to the 
COMELEC to set up help-desks on Election Day, create a database for voters with disabilities, publish relevant information about rights of PWDs, and sensitize Election Officers (EOs) regarding the right to suffrage of voters with disabilities. Official COMELEC records show that all these have been observed to some extent during the 2016 local and national elections when the APP Law was first implemented nationwide.

Since that 2008 CHR Conference, other sectors also made strides towards political inclusion. According to official COMELEC reports, IPs and detainees were able to participate in pilot and/or small-scale special voting projects of the COMELEC between 2010 and 2019. In addition, although migrants were not originally part of the target groups of CHR, it is worth mentioning that the COMELEC now has a dedicated office for overseas absentee voting. These changes came through because COMELEC opened itself to stakeholder consultations and suggestions for reforms, which was largely a result of the investment of IFES in the poll body through sensitization interventions and capacity building trainings.

In particular, TF2010 found reliable allies inside the bureaucracy. The main institutional reformers were COMELEC Commissioner Rene Sarmiento and CHR Chairperson Leila De Lima. Sarmiento articulated the requirements of the vulnerable groups within the COMELEC En Banc, while the support of De Lima in the advocacy process increased the legitimacy and urgency of the disability-inclusive reforms.

Together, De Lima and Sarmiento, acting as institutional reformers, were instrumental in the gains that the marginalized groups were able to achieve over the years in promoting disability-inclusive elections. For instance, a COMELEC Senior Official recalled how Sarmiento led the organization of the Inter-agency and NGO Network on Empowering Persons with Disabilities on February 2011, which became the collaborative space for policy discussion on disability-inclusive elections.

Through Sarmiento, the COMELEC held a National Voter Registration Week for persons with disabilities from July 18, 2011 to July 23, 2011. The COMELEC's report on the activity stressed that the PWDs and their organizations, together with other NGO partners and donor agencies reached out to households to increase the voter registration of the PWD sector. For example, AKAP-PINOY, a national alliance of organizations of PWDs, held an information drive to encourage the members of the sector to register for the polls during that period. On the other hand, the Parish Pastoral Council for Responsible Voting (PPCRV), an established long-time local election watchdog, announced the activity in local Sunday masses across the nation and IFES provided the information materials for the undertaking.

Eventually, the PWD sector managed to launch a full-blown campaign for 
disability-inclusive elections through the establishment of the Fully-Abled Nation (FAN) in 2012. This was a project of The Asia Foundation that received generous funding support from the Australian Government's Department of Foreign Affairs and Trade (DFAT). While TF2010 provided a springboard for the sector's advocacy for political inclusion, the FAN Project galvanized and mobilized the support of the disability community in key areas in the country for the campaign, which were instrumental in operationalizing disability-inclusive elections norms later on.

TAF, like the IFES, shows sustained ideational commitment to governance and democracy as advancing these remain their core purpose for existence. The alignment of DFAT's development priorities in the Philippines with TAF's mission is the cornerstone of their long-term partnership with TAF in the Philippines under the Coalitions for Change program. In 2011, DFAT supported TAF's Increasing the Participation of Persons with Disabilities in the 2013 Philippine Midterm Elections Project, which clearly was more sector-specific, and thus, more focused on the needs of PWDs.

The funding support was crucial for the PWD sector mainly because it enabled them to overcome unique challenges to mobility and participation such as physical access and lack of sign language interpreters and support for the blind. Through TF2010 and the FAN Project, the PWD sector was able to get the COMELEC to issue Resolution Number No. 9485 in 2012 that set out the first guidelines for the establishment of APPs for the 2013 elections as suggested by the sector in the 2008 CHR conference. The APP Act required the provision of ground level polling places in voting centers nationwide that would allow at least ten persons with disabilities and senior citizens voting at the same time (Lapuz 2017).

As an institutional reformer, COMELEC Commissioner Sarmiento actively attended the FAN Project activities such as the voter education caravan. He was also heavily involved in lobbying efforts for the bill in Congress. Meanwhile, according to participants in the FGDs and interviews conducted for this research, the IFES funded the write-shops with legal experts, COMELEC, and the PWD sector to draft the bill on APP based on Resolution No. 9485. The PWD sector leaders served as subject-matter experts. They also participated in lobbying efforts in the legislature (Ibid.).

This coordination between the rights-holders and duty-bearers, however, was not always smooth-sailing. Despite the long campaign for the establishment of the APP Act, come Election Day in May 2013, only two APPs were organized. The National Council for Disability Affairs Executive Director Carmen Zubiaga and newly appointed COMELEC Commissioner Grace Padaca (who replaced Commissioner Sarmiento as lead in disability-inclusive elections initiatives in the COMELEC and a person with disability herself) had a very public disagreement 
over the inability of the COMELEC to deliver APPs across the country in May 2013 (Paredes, Ordenes, Olarte, and Buenaobra 2014).

In addition, TAF commissioned two national surveys concerning the participation of persons with disabilities in elections that proved insightful in the drafting of the APP Law and the general disability-inclusive elections campaign. For instance, knowing that only barely half or $54 \%$ of persons with disabilities voted in May 2013 and that among them, the deaf recorded the lowest participation at $51 \%$, provided a solid argument for policy change (Lapuz 2017).

The FAN Project subsequently launched a host of activities that activated volunteers on the ground. Specifically, its local chapter in Cebu launched the campaign dubbed as "Volunteerism for Disability-Inclusive Elections in 2013" in ten cities and municipalities in the said vote-rich province. Its other members guested in television and radio programs, partnered with local election offices, and helped gather field data to help in information dissemination for elections nationwide. By the end of the registration period, voters with disabilities in Cebu increased by $38 \%$ to 12,608 . The FAN Project convened its members in regular meetings and discussions to present and receive updates from the field (Paredes, Ordenes, Olarte, and Buenaobra 2014).

Already retired, Commissioner Sarmiento lamented the outcome and said that the inter-agency committee should have been consulted prior to Election Day. The COMELEC En Banc relied on technicalities in Resolution No. 9485, which required Election Officers (EO) to notify the head office if they intended to create APPs. Unfortunately, according to Comm. Padaca, only the Dasmariñas EO provided such a manifestation. The Cebu Chapter of the FAN Project responded by saying that the Cebu EOs had been heavily involved in the FAN campaign and had in fact coordinated their APP requirements with the head office as early as December 2012 (Ibid.).

This incident only shows that norm internalization does not translate into automatic on-boarding of domestic political institutions unless clear laws that spell out the operationalization of the said norms are put in place. All these initiatives and engagements in policy-making were constantly supported and documented by TAF.

Nonetheless, the passage of the APP Act in the Philippines is important primarily because of the following: first, it serves as a symbolic win for Filipinos with disabilities who have been outside the nation's political life even after the restoration of democracy in 1986; and second, it recognizes the role of the State in enabling Filipinos with disabilities to exercise their right to vote, signaling a shift in the appreciation of disability in Philippine society, a concrete evidence of norm internalization.

The APP Act authorized the COMELEC to create non-territorial polling precincts for the benefit of voters with disabilities and elderly voters upon their 
request. The law also reiterated the need to make the automated election system used by the Commission friendly to voters with disabilities. Previously, voting in the Philippines could be exercised only in territorial precincts, meaning each voter was classified and clustered by the COMELEC to specific geographical divisions. Voters were not allowed to vote outside their designated precincts; to do so would be to commit an electoral crime. This was not favorable to Filipino voters with disabilities mainly because disability was not considered in the assignment of voters to polling places.

Voters with disabilities would normally endure the inaccessibility of voting centers and social stigma against disability just to be able to exercise their right to suffrage. The PWD sector likewise did not prefer to create a separate territorial polling place for the exclusive use of persons with disabilities because it would reveal how the sector voted and they feared any potential backlash from winning politicians who did not get their support. As such, the APP Act supposedly addressed concerns on accessibility and the uneasiness of the sector with the special polling place (Lapuz 2017).

According to a COMELEC official, the confluence of circumstances presence of policy entrepreneurs and institutional reformers, funding support from development partners, eagerness of the broader civil society to work together, and the enthusiasm of the PWD sector to campaign for policy reformcreated an enabling environment for policy change (Ibid.). Clearly, having policy entrepreneurs and reformers naturally augmented the chances of the advocates to design disability-inclusive elections related policies. These policy champions and advocates would not have been able to express in a national law the political rights of PWDs, $\mathrm{s}$ as enshrined in the UN-CRPD if not for the strategic and dedicated support of policy entrepreneurs such as the IFES and TAF.

\section{1) Other Factors that Led to APP Legislation}

Apart from the strong push from civil society advocates and institutional reformers, getting the senior citizens to support the APP Act meant a greater buy-in from the COMELEC and Congress because as voters, the elderly were more active and established and their population was overwhelmingly significant too. For example, in 2010 the sector's party-list organization ranked second in the party-list elections (i.e. 1,296,520 votes received or $4.42 \%$ of the total ballots cast) (Bueza 2013). This shows that the partnerships that the PWD sector made was valuable in achieving its policy goals, as senior citizens were integrated in the efforts of TF2010.

A comprehensive report on the overall result of the FAN Project's initiatives to make the 2013 mid-term elections accessible was released Furthermore, the independent media outfit VERA Files, in partnership with the 
FAN Project in 2013, published a book to guide reporters on how to cover election stories concerning PWDs (TAF 2018).

\section{CONCLUSION}

The availability of technical and funding support for the disability-inclusive elections campaign spelled a great difference for the PWD sector because it enabled them to overcome the challenges connected to their limited mobility and difficulty to organize. This enabled them to influence the policy agenda not only of the COMELEC but of the Philippine Congress. At the same time, getting assistance in the areas of policy drafting, lobbying work, project development and management, and election monitoring proved to be very useful in their campaign for political inclusion.

The discussion illustrates how norm internalization should be measured not just by reflecting on the state's symbolic adherence to international treaties by ratifying them but also through domestic laws that operationalize such commitment. Policies such as the APP Act translate the Philippines' intention to respect and promote the political rights of PWDs as they engage in actual political processes, including policy advocacy and electoral participation.

In particular, the modified norm life cycle model provided an alternative explanation as to why states initiate electoral reforms that do not necessarily conform with the general idea that policy elites will only want to change election policies if such changes will lead to a direct increase in their political power. Global-centric, macro theories such as those related with norm diffusion are useful in explaining why states adopt policies that they otherwise will neglect absent any outside pressure. Our modified model likewise addresses the criticisms against the original framework as it showed that the internalization of norms in fact occurs in a dynamic, contested, and deliberative process that can take years. In this policy ecosystem, it is important that policy entrepreneurs and policy champions should be sufficiently invested in sustaining their engagement throughout the policy-making process.

Finally, the active participation of the local PWD network in awarenessraising and policy advocacy campaigns also show that they are not just passive bystanders in the norm internalization process. This illustrates that indeed norm internalization cannot take place without various domestic actors claiming their stake in the institutionalization and operationalization of new norms. Indeed, the engagement of policy entrepreneurs, institutional reformers and civil society advocates in the process of norm diffusion, adoption, and internalization shaped the strategic actions leading to the passage of disability-inclusive elections embodied in the 2012 APP Act. 


\section{REFERENCES}

AGENDA. 2013. Accessible Elections for Persons with Disabilities in Five Southeast Asian Countries (Project Report). Jakarta: International Foundation for Electoral Systems.

AGENDA. 2016. Disability Access and Inclusion in the Political Processes of Four Southeast Asian Countries (Project Report). The Center for Election Access of Citizens with Disabilities (PPUA Penca), International Foundation for Electoral Systems.

Bagas, Jonas. 2004. "First Time Voters: A Case of Continuing Political Disenfranchisement," in Friedrich Ebert Stiftung Library, last modified n.d., accessed September 15, 2019, http://library.fes.de/pdf-files/bueros/philippinen/ 50070.pdf

Bowen, Glenn. 2009. "Document Analysis as a Qualitative Research Method." Qualitative Research Journal 9(2): 27-40.

Bueza, Michael. 2013. "Partylist: Senior Citizens disqualified but winning." Rappler. May 22, 2013, accessed June 21, 2018. https://www.rappler. com/nation/politics/elections-2013/29767-party-list-senior-citizens-disqua lified-but-winning.

Caraway, Teri L. 2004. "Inclusion and Democratization: Class, Gender, Race, and the Extension of Suffrage." Comparative Politics 36(4): 443-460.

CHR. 2008. Ensuring the Right to Electoral Participation: Giving Access to Vulnerable Sectors in 2010 (Conference Report). Quezon City, Philippines: Commission on Human Rights.

CMA. 2011. "Policy Paper on Overseas Absentee Voting" in Center for Migrant Advocacy June 13, 2012, accessed September 15, 2019, https://centerformigrantadvocacy.files.wordpress.com/2012/06/policy-paper-on-overseas-abs entee-voting-oav.pdf.

Eisner, E.W. 1991. The Enlightened Eye: Qualitative Inquiry and the Enhamcement of Educational Practice, Toronto: Collier Macmillan Canada.

Finnemore, Martha, and Kathryn Sikkink. 1998. "International Norm Dynamics and Political Change." International Organization 52(4): 887-917.

Fumarco, Luca. 2017. "Disability Discrimination in the Italian Rental Housing Market: A Field Experiment with Blind Tenants." Land Economics 93(4): 567-584.

Harpur, Paul David. 2012. "Embracing the new disability rights paradigm: The importance of the Convention of the Rights of Persons with Disabilities." Disability \& Society 27(1): 1-14.

Hathaway, Oona A. 2007. "Why Do Countries Commit to Human Rights Treaties?" Journal of Conflict Resolution 51(4): 588-621.

Holness, Willen. 2016. "Employment equity and elimination of discrimination: 
Where are women with disabilities in the hierarchy?" Agenda: Empowering Women for Gender Equity 30(1): 49-64.

ICED. 2015. The Economic Costs of Exclusion and Gains of Inclusion of People with Disabilities (Technical Report). UK: International Centre for Evidence in Disability.

IFES and NDI. 2014. Equal Access: How to Include Persons with Disabilities in Elections and Political Processes (Manual). Washington, D.C.: International Foundation for Electoral Systems.

IFES. 2009. International Foundation for Electoral Systems Final Project Report

- Philippines Election Reform Project (Project Report). Washington: United States Agency for International Development.

Jeon, Yongjoo, and Donald P. Haider-Markel. 2001. "Tracing Issue Definition and Policy Change: An Analysis of Disability Images and Policy Response." Policy Studies Journal 29(2): 215-231.

Katz-Suchy, Juliusz. 1948. "One World Through the United Nations." American Academy of Political and Social Science 258(1) 90-100.

Kearney, Alison. 2016. "The right to education: What is happening for disabled students in New Zealand?" Disability Studies Quarterly 36(1).

Kimberlin, Sara E. 2009. "Political Science Theory and Disability." Journal of Human Behavior in the Social Environment 19(1): 26-43.

Kirakosyan, Lyusyena. 2016. "Promoting Disability Rights for a Stronger Democracy in Brazil: The Role of NGOs." Nonprofit and Voluntary Sector Quarterly 45(1S): $114 \mathrm{~S}^{-130 \mathrm{~S} .}$

Lapuz, Paula Bianca. 2017. "Disability-Inclusive Elections: The Experience in the Philippines." (Master's thesis, De La Salle University).

Lloyd-Evans, Sally. 2006. "Focus Groups." In Doing Development Research edited by Vandana Desai and Robert Potter, London: Sage.

Lord, Janet E., Michael Ashley Stein, and János Fiala-Butora. 2014. "Do public representatives in local governments know about "disability rights" in Pakistan? An awareness assessment case from Southern Punjab." Journal of Human Rights Practice 24(4):115-139.

Lune, Howard, and Bruce Berg. 2017. Qualitative Research Methods for the Social Sciences. London: Pearson.

Mercat-Bruns, Marie. 2016. "Comparing European, French, and American Law." In Discrimination at Work, 145-246. Oakland: University of California Press.

Mintrom, Michael, and Phillipa Norman. 2009. "Policy Entrepreneur and Policy Change.” The Policy Studies Journal 37(4): 649-667.

O'Day, Bonnie, and Marcie Goldstein. 2005. "Advancing Strategies for the $21^{\text {st }}$ Century: Key Informant Interviews." Journal of Disability Policy Studies 15(4): 240-250. 
Oliver, Michael. 1990. The Politics of Disablement. Basingstoke: Macmillan.

Paredes, Artha Kira, Lala Ordenes, Avigail M. Olarte, and Maribel Buenaobra. 2014. The Right to Vote: Filipino with Disabilities and the 2013 Elections (Report), Makati City: The Asia Foundation.

Park, Jung Youn. 2017. "Disability discrimination in South Korea: routine and everyday aggressions toward disabled people." Disability \& Society 32(6): 918-922.

Peters, Susan J. 2008. Inequalities in Education for People with Disabilities. Vol. CERC 24, in Inequality in Education: Comparative and International Perspectives, edited by Donald B. Holsinger and W. James Jacob, 149-171. Hongkong: Comparative Education Research Centre

Priestley, Mark, Martha Stickings, Ema Loja, Stefanos Grammenos, Ana Lawson, Lisa Waddington, and Bjarney Fridriksdottir. 2016. "The political participation of disabled people in Europe: Rights, accessibility and activism." Electoral Studies 42: 1-9.

Redley, Marcus. 2008. "Citizens with learning disabilities and the right to vote." Disability \& Society 23(4): 375-384.

Samararatne, Dinesha W.V.A., and Karen Soldatic. 2015. "Inclusions and exclusions in law: experiences of women with disability in rural and war-affected areas in Sri Lanka." Disability \& Society 30(5): 759-772.

Sapire, Hilary. 2009. "Liberation Movements, Exile, and International Solidarity: An Introduction." Journal of Southern African Studies 35(2): 271-286.

Savun, Burcu, and Daniel C. Tirone. 2011. "Foreign Aid, Democratization, and Civil Conflict: How Does Democracy Aid Affect Civil Conflict?" American Journal of Political Science 55(2): 233-246.

Schur, Lisa, and Meera Adya. 2013. "Sidelined or Mainstreamed? Political Participation and Attitudes of People with Disabilities in the United States *." Social Science Quarterly 94(3): 811-839.

Schur, Lisa, Mason Ameri, and Meera Adya. 2017. "Disability, Voter Turnout, and Polling Place Accessibility*." Social Science Quarterly 98(5): 1374-1390.

Schur, Lisa, Meera Adya, and Mason Ameri. 2015. "Accessible Democracy: Reducing Voting Obstacles for People with Disabilities." Election Law Journal: Rules, Politics, and Policy 14(1).

Sen, Amrtya. 2000. Social Exclusion: Concept, Application, and Scrutiny. Social Development Paper, Manila: Office of Environment and Social DevelopmentAsian Development Bank.

Senne, Tshegofatso. 2016. "Deaf women's lived experiences of their constitutional rights in South Africa." Agenda: Empowering women for gender equity 30(1): 65-75.

Shier, Michael, John R. Graham, and Marion E. Jones. 2009. "Barriers to employment 
as experienced by disabled people: a qualitative analysis in Calgary and Regina, Canada." Disability \& Society 24(1): 63-75.

Skinner, Robert. 2017. "The dynamics of anti-apartheid: international solidarity, human rights and decolonization." In Britain, France and the Decolonization of Africa: Future Imperfect? edited by Andrew W.M. Smith and Chris Jeppesen, 111-130. UCL Press.

Spagnuolo, Natalie, and Fady Shanouda. 2017. "Who counts and who is counted? Conversations around voting, access, and divisions in the disability community." Disability \& Society 32(5): 701-719.

TAF. 2018. Count Us In: Fully Abled Nation Making Elections More Inclusive (CfC Reform Story). Pasig City: The Asia Foundation.

Thompson, Vanessa R., Roger J. Stancliffe, Alex Broom, and Nathan J. Wilson. 2014. "Barriers to sexual health provision for people with intellectual disability: A disability service provider and clinician perspective." Journal of Intellectual \& Developmental Disability 39(2): 137-146.

UN-DESA. n.d. "Disability," in United Nations, accessed September 07, 2019. https://www.un.org/development/desa/disabilities/convention-on-the-right s-of-persons-with-disabilities.html

UN-ESCAP. 2017. Disability: The Facts (Briefer). United Nations - Economic and Social Commission for Asia and the Pacific.

Velasco, Djorina. 2005. "Rejecting "Old-Style" Politics? - Youth Participation in the Philippines." In Go! Young Progressives in Southeast Asia, by Jonas Bagas, Joanne Barriga, Ruhan Shahrir Bin Abdul Halim, Augustus Cerdeña, Sara Franz, Kim Eng Yong, Anja Köhler, et al., 107-109. Manila: FES Philippine Office.

Virendrakumar, Bhavisha, Emma Jolley, Eric Badu, and Elena Schmidt. 2018. "Disability inclusive elections in Africa: a systematic review of published and unpublished literature." Disability \& Society 33(4): 509-538.

WHO. 2011. World Report on Disability. World Report, Malta: World Health Organization.

Wright, Joseph. 2009. "How Foreign Aid Can Foster Democratization in Authoritarian Regimes." American Journal of Political Science 53(3): 552-571.

Zwingel, Susanne. 2012. "How Do Norms Travel? Theorizing International Women's Rights in Transnational Perspective." International Studies Quarterly 56(1): 115-129. 